\title{
The Effectiveness of Learning Device With Model Eliciting Activities (MEAS) to Improve Critical Thinking Ability
}

\author{
$1^{\text {st }}$ Utari Oriyenta Mulia \\ Department of Mathematics, Faculty of \\ Mathematics and Natural Sciences, \\ Universitas Negeri Padang \\ Padang, Indonesia \\ muliautarioriyenta@gmail.com
}

\author{
$2^{\text {nd }}$ Ahmad Fauzan \\ Department of Mathematics, Faculty of \\ Mathematics and Natural Sciences, \\ Universitas Negeri Padang \\ Padang, Indonesia \\ fauzan_math@fmipa.unp.ac.id
}

\author{
$3^{\text {rd }}$ Irwan \\ Department of Mathematics, Faculty of \\ Mathematics and Natural Sciences, \\ Universitas Negeri Padang \\ Padang, Indonesia \\ irwan@fmipa.unp.ac.id
}

\begin{abstract}
This research aims to determine the effectiveness of learning device with Model-Eliciting Activities (MEAs) in the form of Lesson Plan and Student's Worksheet. This is a design research and using Plomp with the subject was 36 students class $X$ SMA Negeri 10 Padang. The results that presented here are in the assessment stage. The data were collected through a test. The effectiveness of good categorized products, it is seen from the percentage of students who pass the test is $\mathbf{7 3 , 5 2 \%}$
\end{abstract}

Keywords-Model-Eliciting Activities (MEAs), The critical thinking ability, The effectiveness of a learning device

\section{INTRODUCTION}

Critical thinking ability is one of the standards of ability that must exist in the learning mathematics process. This is because one of the objectives of mathematics learning in the curriculum 2013 is to form thinking and reasoning abilities which are reflected through the critical thinking ability, systematic and objective, honest, discipline in solving a problem either in the field of mathematics or in daily life. This is supported by the statement that learners as educational products are required to have eight competencies, one of which is critical thinking. Furthermore, improving critical thinking ability is very necessary and urgent to be developed in the field of education because it can prepare learners to become critical thinkers, honest and mature, so as to be able to see various challenges [1]. Therefore, it can be concluded that the ability of critical thinking needs to be learners in the learning process

The critical thinking ability is an important component that student must possess. So the students are able to create or formulate, identify, interpret and plan problem-solving. Critical thinking ability includes the ability to analyze, make a conclusion and interpretation, explanation, self-knowledge, curious, systematic, wise to seek the truth and confidence in the thinking process undertaken in an effort to solve problems [3]. In line with Fascione's opinion, critical thinking is an important component that student must have in order to enable them to create or formulate, identify, interpret and plan problem-solving [4].
But the reality that occurs in the learning process still rarely involves critical thinking ability. The learning process at school has not been able to improve the critical thinking ability of learners. The learning process is still centered on the teacher so that students are not paying full attention to learning. At school, there are still many teachers who have not supported what is being done to develop the thinking skills of the student.

The students do more activities that are not related to mathematics in the learning process. Mathematical material and critical thinking are two things that are closely related. This is because the mathematical material can be understood through critical thinking and critical thinking ability trained through learning mathematics [4]. Therefore, need to make improvements in the learning process through learning device improvement needs to be done on the learning process through learning tools. Teachers as facilitators in learning should be able to provide learning tools that are oriented to students to improve the critical thinking skills of students.

Developing critical thinking ability in the learning process can be pursued by developing a learning device. The success of students in learning is largely determined by the instructional device designed by teachers. This is because learning device plays a role to guide the learning process. The availability of learning device will help teachers in implementing the learning process so that the expected goals and learning goals can be achieved. In this study, the learning device developed is Student worksheet.

Student worksheet (LKPD) is an additional resource that can be made by the teacher as a means to improve the critical thinking ability of students. LKPD will direct students to understand a concept and principles so the student can construct their own knowledge. However, LKPD used in schools is generally not designed by teachers so it is not fully in accordance with the characteristics of learners. The limited knowledge and time teachers have in developing effective tools for measuring critical thinking ability is a constraint on the underestimation of the achievement of fundamental goals of mathematics. So, it is necessary to develop an LKPD 
to develop the critical thinking ability of students in class X SMA.

A learning approach that emphasizes the ability to connect mathematical ideas and real phenomena called eliciting activities models [5]. This modeleliciting activities (MEAs) is a bridge between model and interpretation and provides great opportunities for the student to exploit their knowledge in learning mathematics. By using LKPD with eliciting activities model, the learning process becomes meaningful because the student can relate the concepts they learn with the familiar concept. We need to model-eliciting activities in math classes to provide opportunities for students to describe, explain, interpret, construct and communicate relationships, test their hypotheses, and verify solutions [6].

The purpose of this study is to test the effectiveness of the development of learning device in the form LKPD MEAs approach in class X SMA.

\section{METHODS}

This research is a development research that aims to see the effectiveness of mathematics learning device with Model-Eliciting Activities (MEAs). Development of learning tools in this study followed the development procedure according to Plomp. This is because Plomp's development theory is so general that it can be used both for the development of learning models and learning device.

The independent variable in this research is critical thinking ability and approach of Model-Eliciting Activities (MEAs) as the dependent variable. The subjects of the study were class $\mathrm{X}$ students of SMA Negeri 10 Padang.

The instrument used to collect effectiveness data is the final test. The test is done after the students follow the learning using mathematics learning devices with Model-Eliciting Activities (MEAs) approach. Test results are processed by rubric scoring critical thinking ability. The final test is done in writing which consists of 4 pieces of the problem. The indicators used in the final test are 1) assessing facts and evaluating statement statements, 2) collecting and compiling necessary information, 3) using appropriate strategies to solve problems, 4) drawing and testing conclusions. The data analysis technique used is a descriptive statistic to analyze the final test of critical thinking ability.

\section{RESULTS AND DISCUSSION}

The effectiveness of learning device in the form LKPD seen from the extent to which LKPD can help the achievement of learning objectives. LKPD facilitates learners to explore their idea ideas by providing opportunities for students to discuss and illustrate ideas through various activities presented in LKPD.
The effectiveness of instructional devices is related to the impact of learning device on the critical thinking ability of students after learning by using a learning device with Model-Eliciting Activities (MEAs). Indicators to state that the implementation of the Model Eliciting Activities (MEAs) is said to be effective in terms of component components: 1) the learning outcomes of students, 2) the activities of students, 3) the ability of students in mathematics, such as the ability to think critically mathematically. Nieveen (2007) says there are two aspects of effectiveness that must have by a teaching materials, namely 1) experts and practitioners based on practice states that the teaching materials are effective, 2) teaching materials deliver results as expected

The effectiveness of the learning device developed in this research is on the achievement of cognitive learning outcomes that are focused on critical thinking ability. Assessment of the effectiveness of learning devices is measured based on the cognitive learning outcomes of students. Students cognitive learning outcomes are calculated based on the completeness of each student in which the assessment is based on the critical scoring rubric. Analysis of the learning outcomes of students showed that almost some students reaching completeness. Below is shown percentage mastery learners cognitive learning outcomes.

TABLE I. PERCENTAGE OF REACHING COMPLETENESS LEARNING OUTCOMES

\begin{tabular}{|l|l|l|l|}
\hline Class & $\begin{array}{l}\text { The Sum of } \\
\text { Students } \\
\text { that } \\
\text { Reaching } \\
\text { Completen } \\
\text { ess }\end{array}$ & $\begin{array}{l}\text { The Sum of } \\
\text { Students } \\
\text { that } \\
\text { Reaching } \\
\text { Completene } \\
\text { ss }\end{array}$ & $\begin{array}{l}\text { Percentage Of } \\
\text { Reaching } \\
\text { Completeness }\end{array}$ \\
\hline $\begin{array}{l}\mathrm{X} \text { MIA } \\
8\end{array}$ & 23 & 11 & 73,52 \\
\hline
\end{tabular}

Based on the above table it is known that the use of a learning device with the Model Eliciting Activities approach (MEAs) can help students to achieve completeness learning outcomes. In table 1, it is found that many students who achieve the completeness are 23 of 34 students. The students are said to achieve completeness when obtaining a value of $\geqslant 80$.

TABLE II. CRITERIA OF LEARNING OUTCOMES

\begin{tabular}{|l|l|}
\hline \multicolumn{1}{|c|}{ Average } & \multicolumn{1}{c|}{ Criterion } \\
\hline $80<\bar{x} \leq 100$ & Very Good \\
\hline $65<\bar{x} \leq 80$ & Good \\
\hline $55<\bar{x} \leq 65$ & Enough \\
\hline $40<\bar{x} \leq 55$ & Less \\
\hline $\bar{x}<40$ & Failed \\
\hline
\end{tabular}


Based on tables 1 and 2 above, it can be concluded that the critical thinking ability of students has been achieved as expected because it has been in the category of good or greater than $73.52 \%$ and learning device of mathematics with MEAs are said to be effective because the percentage of reaching completeness of students more or equal to $73.52 \%$.In addition to the percentage of reaching completeness, the students also analyzed the percentage of students answers to each indicator of critical thinking ability such as table 3 below:

TABLE III. THE RESULT OF ANALYSIS OF CRITICAL THINKING OF EACH INDIKATOR

\begin{tabular}{|c|c|c|c|c|c|c|}
\hline \multirow{2}{*}{$\begin{array}{l}\mathrm{N} \\
\mathrm{O}\end{array}$} & \multirow{2}{*}{$\begin{array}{c}\text { Indicat } \\
\text { or }\end{array}$} & \multicolumn{4}{|c|}{ Sum of Students } & \multirow{2}{*}{$\begin{array}{l}\text { Ave } \\
\text { rage }\end{array}$} \\
\hline & & $\begin{array}{c}\text { Score } \\
0\end{array}$ & $\begin{array}{c}\text { Score } \\
1\end{array}$ & $\begin{array}{c}\text { Score } \\
2\end{array}$ & $\begin{array}{c}\text { Score } \\
\mathbf{3}\end{array}$ & \\
\hline 1 & $\begin{array}{l}\text { Assess } \\
\text { facts } \\
\text { and } \\
\text { evalua } \\
\text { te } \\
\text { statem } \\
\text { ents }\end{array}$ & - & 8 & 13 & 14 & 2,2 \\
\hline 2 & $\begin{array}{l}\text { Collect } \\
\text { and } \\
\text { arrange } \\
\text { the } \\
\text { necessa } \\
\text { ry } \\
\text { informa } \\
\text { tion }\end{array}$ & - & 3 & 19 & 13 & 2,3 \\
\hline 3 & $\begin{array}{l}\text { Use the } \\
\text { right } \\
\text { strategy } \\
\text { to solve } \\
\text { the } \\
\text { proble } \\
\text { m }\end{array}$ & - & 3 & 8 & 24 & 2,6 \\
\hline 4 & $\begin{array}{l}\text { Make } \\
\text { and } \\
\text { verify } \\
\text { the } \\
\text { conclus } \\
\text { ion }\end{array}$ & 2 & 3 & 16 & 14 & 2,2 \\
\hline
\end{tabular}

Based on the above table, that half of the number of students has reached the score 2 and 3 . This shows that the critical thinking ability of students using learning device in the form of LKPD with MEAs represented by four indicators are optimal. This means learning devices with MEAs have an impact on cognitive learning outcomes of students. Learning device of mathematics developed are said to be effective because there are successes generated by students after following the learning by using the learning device mathematics with Model-Eliciting Activities (MEAs) approach. For each component of effectiveness must be clearly defined, for example, the critical thinking ability of students referred to in this study are the numbers obtained through scoring by using assessment instruments, such as exercise questions and critical thinking ability tests at the end of the trial.

So, based on the data that has been obtained in there is an important point that the use of the learning device with MEAs can improve student learning outcomes. So that learning device with MEAs has been effective.

\section{CONCLUSIONS}

Based on the results above, we can conclude that the learning device with MEAs are effective because it gives a positive effect on the critical thinking ability of students. This can be seen from improving students learning outcomes of the given test.

\section{REFERENCES}

[1] Hasratuddin, "Meningkatkan Kemampuan Berpikir Kritis Peserta didik Smp Melalui Pendekatan Matematika Realistik", Jurnal Matematika Jurusan Matematika FMIPA UNIMED vol. 4. no.2, pp. 19-21, Desember 2010.

[2] Facione, P A. 1992. Critical Thinking:What It is and Why It Counts. http://www.student.uwa.edu.au

[3] Mahmuzah R, "Peningkatan Kemampuan Berpikir Kritis Matematis Siswa SMP MelaluiPendekatan Problem Posing" vol. 4 no 1, pp. 2302-5158, 2015.

[4] Lesh , R.A, \& Doerr, H, "Foundations of model and modeling perspectives on mathematic teaching and learning. In R.A. Lesh and H. Doerr (Eds.), Beyond Constructivism: A modelsand modeling perspectives on mathematics teaching, learning, and problem solving. Mahwah, NJ: Lawrance Erlbaum, 2003.

[5] Eraslan, A, "Prospective Elementary Mathematics Teachers Perceptions On Model Eliciting Activities and Their Effects on Mathematics Learning." The Journal of Elementary Education Online, vol. 10 no. 1, pp. 364-377, 2011. 